\title{
Potato Value Chain Analysis in Banja District, Ethiopia
}

\author{
Melkamu Bazie Fentie ${ }^{1}$ Degye Goshu ${ }^{2} \quad$ Bosena Tegegne ${ }^{2}$ \\ 1.Agricultural Economics Research Department, Ethiopian Institute of Agricultural Research at Fogera National \\ Rice Research and Training Center, Woreta, Ethiopia \\ 2.Department of Agricultural Economics and Agribusiness, Haramaya University, Haramaya, Ethiopia
}

\begin{abstract}
Potato is important for its contribution to food security and as source of cash income for a large proportion of the rural households. However, enhancing potato farmers to reach markets and actively engage in the potato value chain is a key issue needed in the study area. This paper was aimed to identify Potato value chains and their performance. The data collected from randomly selected 120 farmers and from purposively selected 42 traders and 35 consumers. Descriptive analysis was used for characterizing farmers, describing value chain and examining market performance. Input suppliers, farmers, collectors, wholesalers, retailers and consumers were main value chain actors and governmental offices and NGOs were support service providers. The product passed through different channels and went out to different destination markets. Out of the total costs of production, seed cost accounts $38.43 \%$ of the total production cost to farmers and net return of $27.33 \%$ selling price. Even though the study area has high potential for potato production, there are constraints from input supply to consumption stages. Product perishability and lack of storage, seed system, and irrigation access and price fluctuation are some of the problems seen in the potato value chain. Therefore, the study underscores seed supply system, expansion of irrigation access, improvement on storage and postharvest processing methods and strengthening of cooperatives for policy implications.
\end{abstract}

Keywords: Potato value chain, performance, constraints

DOI: $10.7176 / \mathrm{FSQM} / 95-02$

Publication date:March $31^{\text {st }} 2020$

\section{Introduction}

Potato is the fourth most important world food crop after wheat, rice, and maize (Joshi and Gurung, 2009). It is the fastest growing food crop in Sub Saharan Africa with the total production in some countries more than doubled during the last 15 years. This is similar to the development in Asia (China and India) where area and yield increased strongly (CIP, 2008). The crop was introduced to Ethiopia in 1859 by a German scientist called Schimper (Pankrust, 1964). Since then it was limited to homestead as a garden crop and gradual rise in production occurred at the end of $20^{\text {th }}$ century, when there was a long famine in Ethiopia (Gebremedhin et al., 2008).

In Ethiopia, $70 \%$ available agricultural land is located at an altitude of $1800-2500 \mathrm{~m}$ which is suitable for potato production (FAO, 2008; Endale et al., 2008). The national production of potato reached 932,701 tonnes with area coverage of 67,591 ha in the year 2017 (FAO, 2017). About 1.57 million small farmers were practiced in potato farming (CSA, 2013). It is produced in Oromia, Amhara, SNNPR and Tigray regions, which constitute $46 \%, 34 \%, 19 \%$ and $1 \%$ of the national potato production, respectively (CSA, 2012). Even though potato is grown by more than one million smallholder farmers in the highlands of the country, the national productivity of potato is ranging between 7-13 tons per hectare between the periods 2008 to 2017. This is very low compared to Asian and other countries in the world as a highland country located in the tropics and has very favorable conditions for the production of high quality potato (FAO, 2017).

Ethiopian farmer's main objective of growing potato is to ensure adequate food supply during food shortage months. It is the best staple food crop during this period as well as an important source of cash income (Gebremedhin et al., 2013), because of its ability to provide a high yield of high-quality product per unit of input with a shorter crop cycle than major cereal crops like maize (Adane et al., 2010). Potato has been considered as a strategic crop by the Ethiopian government aiming at enhancing food security and economic benefits to the country (EIA, 2012). As the population grows rapidly, increased productivity of potatoes can improve the livelihood of smallholder potato producers and is required to meet the growing demand (Gildemacher, 2012).

Potato provides an opportunity for domestic value chain development. Potato value chains cover all activities from input supply, production, processing, wholesale and retailing to the final consumer (Haggblade et al., 2012). Potato provides huge opportunity and there are good prospects for value addition, this opens wider room for commercial investment in key value chains (AGRIBiz, 2015).

Potato is traded in local market and export market outlets, which is an essential activity of the farming households where it generates income and has contributed to the development of potato sector (Tekalign, 2010). Potato is becoming among the major vegetable export products the increasing of export of potato to Somaliland and Djibouti is major motive for potato farmers in Eastern Ethiopia (Bezabih and Hadera, 2007). According to FAO (2017), Ethiopia was exported 89193 tonnes of potatoes and valued 23 million US Dollar. 
Ethiopia has a comparative advantage in a number of horticultural commodities due to its favorable climate, proximity to European and Middle Eastern markets and availability of labour. However, the production of horticultural crops is much less developed than the production of food grains in the country. Out of the total land area under cultivation in the country, land under fruits and vegetables is insignificant as compared to food crops (EIA, 2012). In the study area, potato is the main crop for farmers which were producing for household food consumption and as source of cash income. However, there are problems related to potato in the country in general and in the study area in particular; starting from Input supply stage through production, marketing to the point of consumption and at value chain enablers (Bezabih and Mengistu, 2011; kassa, 2014; Yazie et al., 2009). Understanding of the existing inputs supply, production, marketing systems and consumption of potato is important for developing/upgrading value chain in the study area.

It is important to value chain actors in which strengthen potato value chain has to be improved. So, this study was proposed to analysis potato value chain in Banja district, Awi zone of Amhara region, Ethiopia for the purpose of providing vital information for effective research, planning and better intervention by government and other stockholders. The general objective of the study is to analyze the value chain of potato in the study area. The Objective of the study is to map potato value chain, identify actors, their roles and linkages; and to evaluate market performance in the value chain.

\section{RESEARCH METHODOLOGY}

\subsection{Description of the Study Area}

This study was conducted in Banja district, is one of the districts' found in Awi zone of Amhara region, Ethiopia. Banja district is bordered on the south by Ankesha, on the West by Guangua, on the North by FagetaLekoma and in the East by the West Gojam zone Injibara town is the capital of Banja district. It is located about $442 \mathrm{kms}$ North West to Addis Ababa and $116 \mathrm{kms}$ south of Bahir Dar as shown in fig 1.

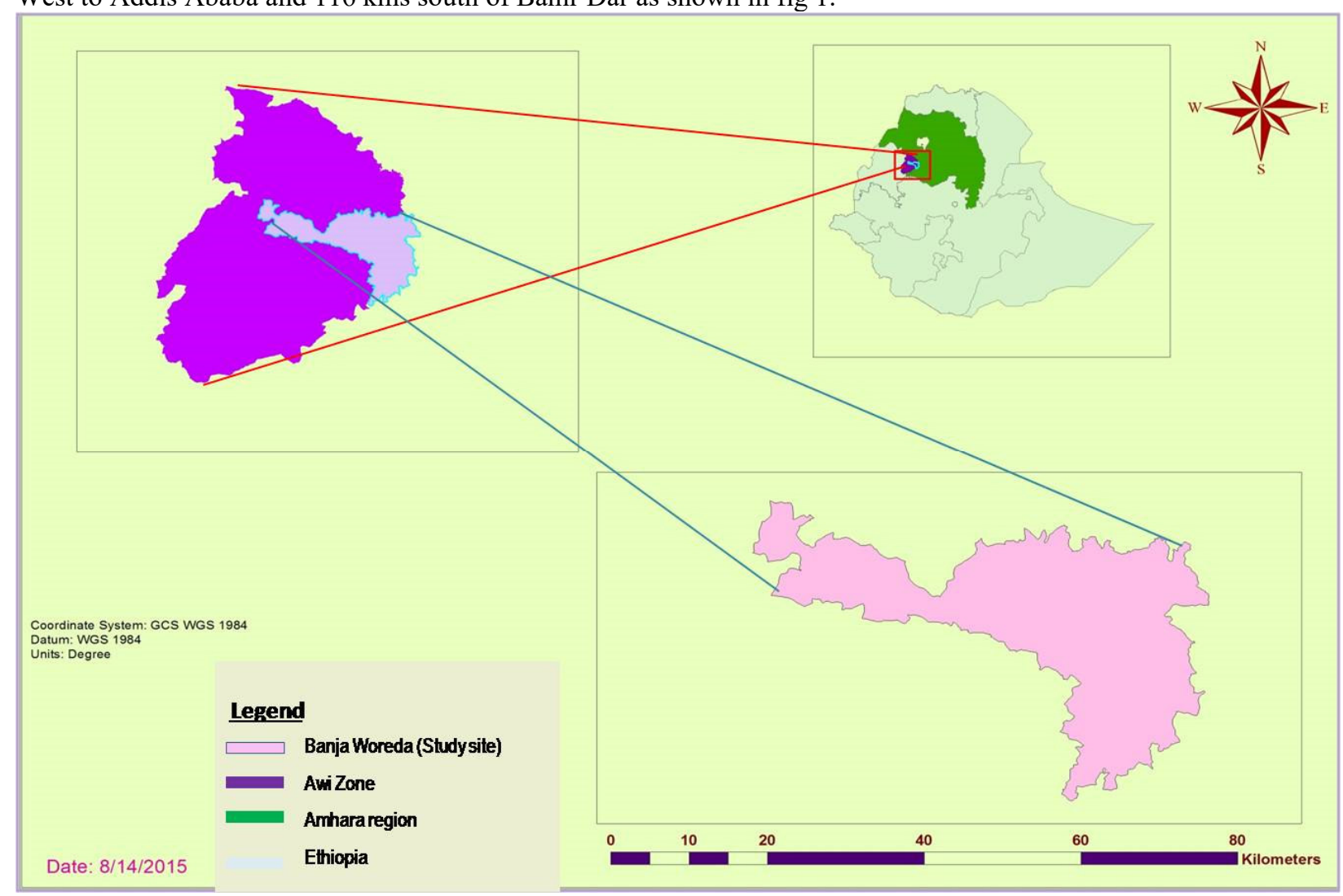

Figure 1. Location of the study area

Source: Adopted and manipulated from Ethiopian map

\subsection{Data Types, Sources and Methods of Data Collection}

Both secondary and primary data were used for this study. Primary data was collected using informal and formal surveys. Primary data were collected through interview questionnaire and key informant interview and focus group discussions with different value chain actors and agricultural experts. The formal survey was undertaken through interviews with selected potato producer farmers, traders and consumers using a pre-tested questionnaire for each value chain actor. Key informants interview was conducted with input suppliers, potato traders, district agricultural 
experts, marketing experts and end users. For this purpose, different guiding questionnaires were prepared and used. Secondary data was collected from Central Statistical Agency (CSA), Bureau of Agriculture and Rural Development (BoARD), Agricultural Research Centers, Local level Trade Offices, NGOs', published and unpublished documents, and internet sources.

\subsection{Sampling Techniques and Sample Size}

The study area, Banja district, was selected as a study area since the area has high potential for potato production and marketing. Samples were selected from each segment of the value chain using diverse sampling techniques.

For sampling producers, a multi-stage sampling technique was implemented. The district has 25 rural kebeles, 20 of them produce potato. In the first stage, all potato producer kebelesin the district were selected purposively. In the second stage, from these potato producer kebeles, 5 sample kebeles were selected randomly as shown in table 1. In the third stage, the study considered only potato producer households. Thus, from each sampled kebele potato producer farmers were listed out with the help of development agents at kebele level. From these population lists, sample farmers were selected randomly based on probability proportional to size sampling technique.

For this study the total sample size for sample household farmers was determined based on the sampling formula provided by (Yamane, 1967). The formula used for sample size determination with $95 \%$ confidence level, degree of variability $=0.5$ and level of precision $9 \%(0.09)$ was:

$$
n=\frac{N}{1+N\left(e^{2)}\right.}
$$

Where: $\mathrm{n}=$ Sample size, $\mathrm{N}=$ Population size and $\mathrm{e}=$ level of precision Based on the above formula a total of 120 households were interviewed. Table 1. Distribution of sample households in the district

\begin{tabular}{lcc}
\hline Sample kebeles & Number of potato producer households & Number of sample households \\
\hline Askuna Abo & 979 & 37 \\
ZufariAbsketem & 678 & 25 \\
AkenaJefi & 624 & 23 \\
WuslaKindikan & 593 & 22 \\
GashenAkayta & 352 & 13 \\
\hline Total & 3226 & 120 \\
\hline
\end{tabular}

Source: Own computation, 2015

Sample traders were taken at different stages of the value chain. Hence, a purposive sampling method was used to select wholesalers (13), rural collectors (8) and retailers (21) from the markets that potato passed through. Accordingly, a total of 42 traders were selected from Kedamaja, Kessa, Merketa of district rural markets and from Injibara, Chagni, Bahir Dar, and Gondar markets. Furthermore, 5 potato seed traders (suppliers) and 35 consumers were interviewed.

\subsection{Methods of Data Analysis}

Descriptive statistics was used to analyze the data collected, employed maps, graphs, percentages, frequencies, means and standard deviations. To evaluate the market performance in the value chain net returns and estimated costs of value chain actors along the value chain were calculated.

\section{Results and Discussion}

\subsection{Actors and Their Roles in Potato Value Chain}

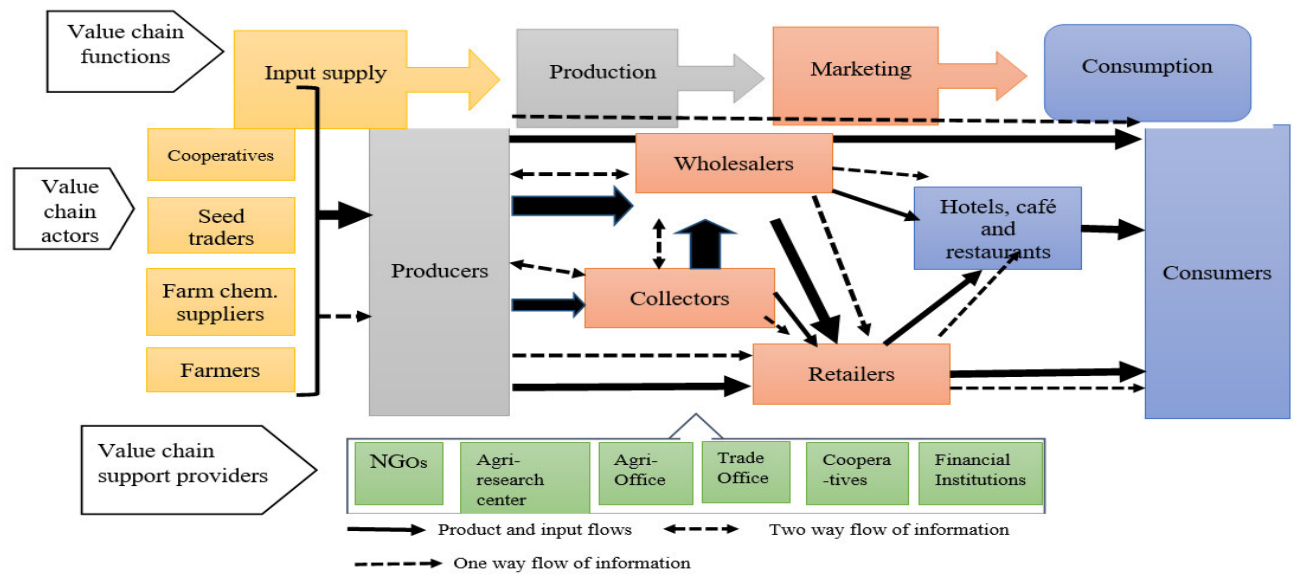

Figure 2. Potato value chain map; Source: Sketched from own survey, 2015 
The value chain map of potato in Banja district is presented in Figure 2, the two potato value chain actors were identified namely direct actors those are input suppliers, producers, traders, consumers and indirect actors were those that provide financial or non-financial support services, such as government offices, research institutions, credit agencies, business service providers, NGOs and cooperatives.

Input Suppliers: Primary multipurpose farmers' cooperatives, seed suppliers (traders), NGOs and private agricultural chemicals suppliers were the main actors in performing input supply function to producers. Potato farmers also participated in preparing their own inputs and they also supply to fellow farmers. Over all, these actors supplied seeds, fertilizers, chemicals and farm implements.

In the study area, farmers use organic fertilizer (manure and compost) prepared by farmers themselves and inorganic fertilizers supplied from cooperatives. Out of the total interviewed households 54.17\% used DAP fertilizer, 26.67\% used Urea fertilizer, $52.5 \%$ used animal manure and $80.83 \%$ used compost (Table 2). About $15 \%$ of farmers used chemical for controlling potato diseases. Chemicals are supplied by private farm chemical suppliers found mainly in urban market (town). Farmers use different local farm tools for digging and traction by purchasing from local markets.

Table 2. Input use and sources

\begin{tabular}{lllllll}
\hline Inputs & Proportion of farmers Used (\%) & \multicolumn{3}{l}{ Source of inputs $(\%)$} \\
\cline { 3 - 7 } & & Own & $\begin{array}{l}\text { Traders } \\
\text { (market) }\end{array}$ & $\begin{array}{l}\text { Fellow } \\
\text { Farmer }\end{array}$ & NGO & Cooperatives \\
\hline Seed & 100 & 45.3 & 69.47 & 5.08 & 2.54 & \\
DAP Fertilizer & 54.17 & & & 1.52 & 1.52 & 96.97 \\
Urea Fertilizer & 26.67 & & & 3.13 & 3.13 & 93.75 \\
Manure & 52.5 & 100 & & & & \\
Compost & 80.83 & 100 & & & & \\
Farm chemicals & 15 & & 100 & & & \\
Farm implements & 99.15 & 88.89 & 11.11 & & 1.71 \\
\hline
\end{tabular}

Source: Own survey result, 2015

A larger proportion of farmers $(69.47 \%)$ was purchased seed from private traders at markets. This contradicts with the finding of Kassa (2014) the most common seed sources were producers themselves. There are seed suppliers in rural and urban markets of the district who have trade license of retailing and wholesaling. Their initial supply source is spread in different towns of East Gojam, West Gojam and South Gonder Zones. The wholesalers purchased seed potato from traders in Debremarkos, Feresbet, Adet, Waber, Quarit. Gayinet and KiemerDengaymarkets.the wholesalers transport by vehicles and sell directly to farmers and retailers. Retailers again sell to farmers. According to discussion with key informant seed suppliers, a larger proportion of the seed potatoes to the district were supplied from Adet and Debremarkosareas.

Producers: Potato producers in the study area are smallholder farmers. The average own land holding was the area is 1.37 ha per household. The farmers on average allocated 0.30 ha of land with a range of 0.04 ha to 1 ha for potato production the year 2015 (Table 3). Average production was $32.72 \mathrm{Qt}$ and the average yield was 114.47 $\mathrm{Qt} / \mathrm{ha}$ this finding is lower than national average estimate of $136.85 \mathrm{Qt} / \mathrm{ha}$ (CSA, 2015). The reason for low yield was mainly the prevalence of potato diseases and insects in the area.

Table 3. Land holding, allocation and production of potato

\begin{tabular}{llllll}
\hline Variable & $\mathrm{N}$ & Mean & Std. Dev. & Min & Max \\
\hline Total land holding (ha) & 120 & 1.37 & 0.59 & 0 & 3 \\
Land size allocated for potato production (ha) & 120 & 0.30 & 0.17 & 0.04 & 1 \\
Quantity of potato produced (Qt) & 120 & 32.7 & 29.65 & 3.6 & 249 \\
Yield (Qt/ha) & 120 & 114.47 & 68.10 & 19.2 & 300 \\
\hline
\end{tabular}

Source: Own survey result, 2015

Irrigation, rain fed (meher season) and residual moisture based potato production systems are commonly practiced in the study area. Out of the total area covered by potato $59.19 \%$ was produced by irrigation, $30.70 \%$ by rain fed system (meher season) and the rest $10.12 \%$ by residual moisture. In terms of quantity of production, $77.24 \%, 17.83 \%$ and $4.93 \%$ was produced by irrigation, meher and residual moisture, respectively (Table 4). This indicates that the production of potato through use of irrigation system takes the largest share and contribution. Table 4. Potato land coverage and output by production systems

\begin{tabular}{lll}
\hline Production system & Area coverage (\%) & Production (\%) \\
\hline Rain fed & 30.70 & 17.83 \\
Irrigation & 59.19 & 77.24 \\
Residual moisture & 10.12 & 4.93 \\
\hline
\end{tabular}

Source: Own survey result, 2015 
Potato sole cropping is the most popularly practiced cropping pattern in the study area. About $75.93 \%$ of producers reported that they practice sole cropping and $24.07 \%$ practice intercropping with crops like beans and maize. Sample farmers sell their potato product at the available market options which were farm gate and nearest village market and urban (town) market to different value chain actors like collectors, wholesalers, retailers and consumers (including individual households, hotels and restaurants). Larger proportion of the sample households sold potato at farm gate and village market. Farm gate sales occur in kebeles which have good access to irrigation. In these kebeles there are practices of selling potato to traders when potato is on the farmland before the product is harvested. When this happen the harvesting, packaging, sorting and transporting functions are performed by the buyer (either collector or wholesaler), the farmers negotiate sales with collectors/wholesalers either for selling on credit or cash even though they do not know exactly how much output will be produced. Those farmers who sold their product at urban market perform post-harvest activities like sorting, packaging, storing and transportation by themselves. The respondents used human back load (26.44\%), Donkey/horseback load (26.44\%) and animal carts $(13.22 \%)$ for transporting their product to their preferred market and used plastic sacks for packaging as shown in table 5 .

Collectors: Collectors are found in village markets, most have trade license on vegetables and fruits trading. During peak harvest seasons February to end of June they assemble potato from farmers either at farm gate or from nearest market for the purpose of reselling to wholesalers that found in the same kebeles or wholesalers from Chagni, Injibara and those who come from other places and also to retailers at urban market. They also retail seed potato (supply input) to farmers October to end of January. These collectors communicate with wholesalers and asses the demand for the product before going to purchase. They do not store the collected potato for more than 3 days because of the fear of loss due to product perishability. Some collectors receive in advance payment from wholesalers and assemble the product. In the study area, it is common the collectors negotiate with farmers to purchase potato at farm field and collectors use hired daily laborers to harvest a product. They use horse/mule carts for transporting the product from farm gate to their work place (storage house) and also use human back loading to areas which is not accessible for carts.

Wholesalers: They handle large volume than other value chain actors were purchasing from collectors and producers to resell to wholesalers, retailers and/or consumers. In the study district wholesalers found in markets like kidamaja, Injibara and Chagni markets. Wholesalers at local market were selling potato through cell phone communication with traders in different cities in the country.

Retailers: There were considerable number of retailers who traded potato with other vegetables like onion, tomato, cabbage, green pepper and other vegetables. Retailers purchased potato mainly from wholesalers $(55.39 \%$ of the total volume) followed by producers $(42.73 \%)$ and the rest $1.88 \%$ from collectors for reselling to consumers (including individual households, hotels, cafes, restaurants and road vendors)

Consumers: Consumers are found in both rural and urban areas include individual households, institutions, hotels, café and restaurants. They purchased $65.94 \%, 31.87 \%$ and $2.18 \%$ of the total quantity of potato from retailers, farmers and wholesalers, respectively. The consumers' survey result showed that individual household's per capita consumption of potato was from 40 to 300 birr per month spent to purchase of potato.

Value chain support providers: In the study area, different governmental and non-governmental organizations supporting potato value chain. District Agricultural Offices, Trade and Transport Office, Primary Farmers' Cooperatives, Amhara Saving and Credit Institution, Private Transporters and NGOs (IFAD, GIZ-SLM) are value chain supporters identified in the study area. Some service providers extend their supportive functions along the value chain and also have multiple functions. Agricultural offices provided agricultural extension services, follow closely the potato farmers, they advise on potato cultivation, management of agronomic practices and organizing and providing trainings. In kebeles where irrigation is accessible, there are irrigation development cooperatives which established for the aim of supplying different inputs, purchase crop products grown by irrigation and management of irrigation water. But, in the area only irrigation water management and controlling activities were done by this cooperatives regarding to potato sub sector. These cooperatives were neither supply seed potato nor purchase potato product. The key informants from these kebeles mentioned that in the earlier time the irrigation development cooperatives had been started to supply potato seed but they stopped supplying because of high lose due to perishability now. Multi-purpose primary cooperatives have a responsibilities and duties on supplying different agricultural inputs and purchase farmers produce. But the information from the study showed that these multi-purpose primary cooperative were only supplying fertilizers, both DAP and Urea either on cash or on credit to potato producer farmers.

Amhara Credit and Saving Institution (ACSI) and commercial banks provide credit services for the potato value chain actors. International Fund for Agricultural Development (IFAD) an international NGO provide supportive functions in the district through PASIDP. Participatory Small Scale Irrigation Development Program (PASIDP) has primary objective to develop sustainable farmer owned and managed system of small scale irrigated agriculture. It has been working in three selected kebeles in the district. International Fund for Agricultural Development (IFAD) provided services starting from small scale irrigation development up to advisory services 
in potato sub sector to farmers. It was performing different activities like irrigation water development, capacity development activities to producers, Kebele and woreda agricultural experts, support primary irrigation development cooperatives and kebele FTCs through material (office furniture, equipment) and financial services.. Additionally, IFAD supports female headed farm households in training and providing the irrigation equipment (rope pump), promote potato seed technology distribution. The services provided by IFAD were encouraging especially construction of irrigation dams, helps farmers to have improved livelihood according to information obtained from farmers FGD.

GIZ, an international German based NGO, support producers in the study areas through Sustainable Land Management and Global Climate Change Adaptation (SLM) project. This development project participated in improved potato seed supply in the year 2015 in the district.

\subsection{Market Performance in Potato Value Chain}

Seven marketing channels were identified for potato value chain in the study district. The channel comparison was made based on volume passed through. Accordingly, a channel of Farmers $\rightarrow$ Wholesalers $\rightarrow$ Retailers $\rightarrow$ consumers is the largest in which about $35.66 \%$ of the product passed through(channel 4 ) and followed by a channel of Farmers $\rightarrow$ Collectors $\rightarrow$ Wholesalers $\rightarrow$ Retailers $\rightarrow$ Consumers in which $21.23 \%$ of the product passed through it (channel 1).

Channel 1.Farmers $\rightarrow$ Collectors $\rightarrow$ Wholesalers $\rightarrow$ Retailers $\rightarrow$ Consumers $(21.23 \%)$

Channel 2.Farmers $\rightarrow$ Consumers (13.9\%)

Channel 3. Farmers $\rightarrow$ Collectors $\rightarrow$ Retailers $\rightarrow$ Consumers $(0.82 \%)$

Channel 4.Farmers $\rightarrow$ Wholesalers $\rightarrow$ Retailers $\rightarrow$ Consumers $(35.66 \%)$

Channel 5.Farmers $\rightarrow$ Wholesalers $\rightarrow$ Consumers (11.04\%)

Channel 6.Farmers $\rightarrow$ Collectors $\rightarrow$ Wholesalers $\rightarrow$ Consumers $(6.57 \%)$

Channel 7.Farmers $\rightarrow$ Retailers $\rightarrow$ Consumers $\rightarrow(10.78 \%)$

Farmers sold about $46.69 \%$ of their potato to wholesalers, $28.63 \%$ to collectors, $10.78 \%$ to retailers and $13.9 \%$ to consumers.

Potato produced in the district went outside different cities to different regions during the peak harvesting season. Out of the total quantity of potato supplied to the market, it was estimated that $32 \%$ consumed in the district the remaining $68 \%$ were transported to outside the district to different cities across the country. Out of the total quantity of potato flowed outside the district, larger proportion of potato transported to Gonder which accounted $31.53 \%, 26.69 \%$ to Bahir Dar, $13.53 \%$ to Addis Ababa, and the remaining 28.25\% flow to Jawi, Mekele, Metema, and cities found in Benshangul Gumuz region like Gelgel, Pawi and Debatsi (Table 5).

Table 5.Banja district potato geographical flow to different destinations

\begin{tabular}{ll}
\hline Name of city/town & Percentage \\
\hline Gonder & 31.53 \\
Bahir Dar & 26.69 \\
Addis Ababa & 13.53 \\
Others & 28.25 \\
\hline
\end{tabular}

Source: Own survey result, 2015

In conducting profitability analysis of potato production, market prices for purchased inputs and output were considered. For inputs like family labor, exchange labor, own animal draft power, own land and other inputs which the households use in potato production without paying direct cost, its opportunity costs were used. Sampled farmers sold potato product in fresh form so the reference product was taken in fresh potato form. Prices differ per marketing channel, per quantity sold, change over the season, and even prices can vary during one single day. Therefore, weighted average price was used in analyzing profitability of potato production and marketing for the value chain actors.

As observed in Table 6, the average production cost of potato was $137.02 \mathrm{birr} / \mathrm{Qt}$. Out of the total costs of production, seed accounts $38.43 \%$ of the total production cost which was major cost component in potato production. Bezabih and Mengistu (2011) found that the largest input cost was seed in production of potato in South and Tigray regions of Ethiopia. The average selling price was 212.07 birr/Qt and net return of farmers from potato production was estimated at 58.06 birr/Qt, which is $27.33 \%$ their selling price and $37.7 \%$ of total cost in the year $2014 / 15$. The study result is low as compared with the study of potato value chain in Dedo district of Jima zone, Ethiopia while the producers net profit was $45.35 \%$ of selling price and $82.9 \%$ of total cost Abduselam et al (2018) This variation could be arise from types of market agency where farmers were selling and land allocation affected vegetables production profitability in Swaziland (Masuku and Xaba, 2013). 
Table 6. Profitability analysis of potato producer sample farm households

\begin{tabular}{|c|c|c|}
\hline \multirow[t]{2}{*}{ Input cost items } & \multicolumn{2}{|c|}{ Average costs } \\
\hline & Birr/Qt & Production cost $(\%)$ \\
\hline \multicolumn{3}{|l|}{ Land preparation } \\
\hline Draft power & 16.09 & 11.74 \\
\hline Labor & 10.73 & 7.83 \\
\hline Total land preparation costs & 26.82 & 19.57 \\
\hline \multicolumn{3}{|l|}{ Planting and crop management } \\
\hline Seeding and fertilizing (labor) cost & 6.91 & 5.04 \\
\hline Weeding and digging(labor) cost & 10.14 & 7.40 \\
\hline Watering labor cost & 2.3 & 1.68 \\
\hline Harvesting labor cost & 9.38 & 6.85 \\
\hline Total planting and crop management labor costs & 28.73 & 20.97 \\
\hline Seed cost & 52.65 & 38.43 \\
\hline \multicolumn{3}{|l|}{ Other material input Costs } \\
\hline Chemical cost & 0.76 & 0.55 \\
\hline Farm tools purchase & 0.3 & 0.22 \\
\hline Total Fertilizer cost & 9.89 & 7.22 \\
\hline Total other material costs & 10.95 & 7.99 \\
\hline Land rent & 17.09 & 12.47 \\
\hline Interest on browed money & 0.78 & 0.57 \\
\hline Total production costs & 137.02 & \\
\hline \multicolumn{3}{|l|}{ Marketing costs } \\
\hline Selling cost (labor) & 3.35 & \\
\hline Storage cost & 6.05 & \\
\hline Packing materials & 2.45 & \\
\hline Transport, loading and unloading cost & 5.05 & \\
\hline Other costs & 0.09 & \\
\hline Total marketing costs & 16.99 & \\
\hline Overall totalcost & 154.01 & \\
\hline Selling price & 212.07 & \\
\hline Net-return & 58.06 & \\
\hline
\end{tabular}

$\mathrm{Qt}=$ quintal, \% = percentage

Source: Own survey result, 2015

Table 7,depicts the total cost and net return of different actors from a quintal of potato, retailers in general get highest net return per quintal than other value chain actors followed by wholesalers and the least earner was collectors. Among retailers, retailers of Injibara town earn highest percentage of net profit that was a net return about $104.58 \%$ of the purchase price. But this does not mean that retailers are generating more profit in total than other actors. Even if they get highest net profit per unit, they handle small quantity of potato than other trade actors their total profit are low. This finding in line with Dawit and Fitsum (2016), retailers earn the highest marketing margin from all other vegetable traders in East Shoa, Ethiopia. Wholesaler's total benefit is greater than the others because they handle large volume.

Table 7. Costs and net returns of value chain actors (Birr/Quental)

\begin{tabular}{llllllllll}
\hline Cost items & Collectors & \multicolumn{2}{l}{ Wholesalers } & \multicolumn{3}{l}{ Retailers } \\
\cline { 3 - 10 } & & Injibara & Chagni & $\begin{array}{l}\text { Bahir } \\
\text { Dar }\end{array}$ & Gonder & Injibara & Chagni & $\begin{array}{l}\text { Bahir } \\
\text { Dar }\end{array}$ & Gonder \\
\hline $\begin{array}{l}\text { Purchase price } \\
\text { Total marking }\end{array}$ & 212.07 & 277.2 & 239.83 & 324.3 & 324.3 & 245 & 255.46 & 442.5 & 538.81 \\
$\begin{array}{l}\text { cost } \\
\text { Total overhead }\end{array}$ & 2.05 & 10.35 & 33.55 & 59.86 & 113.13 & 7.95 & 7.1 & 17.67 & 20.25 \\
$\begin{array}{l}\text { cost } \\
\text { Total cost }\end{array}$ & 45.09 & 13.13 & 40.04 & 63.03 & 114.51 & 17.18 & 39.9 & 31.48 & 34.45 \\
$\begin{array}{l}\text { Selling price } \\
\text { Net return/ }\end{array}$ & 277.16 & 325.29 & 327.87 & 442.33 & 538.81 & 518.41 & 477.4 & 674.81 & 859.45 \\
profit & 20 & 35 & 48 & 55 & 100 & 256.23 & 182.04 & 200.87 & 286.19 \\
Net return (\%) & 9.43 & 12.63 & 20.01 & 16.96 & 30.84 & 104.58 & 71.26 & 45.39 & 53.12 \\
\hline
\end{tabular}

Source: Own survey result, 2015 


\subsection{Constraints and Opportunities in Potato Value Chain}

Even though potato is widely grown and marketed for a long time in the study area, farmers face many constraints. In the study area, disease and insects, shortage of improved seed, natural hazards (frost, high rain fall), irrigation shortage, product perishability and lack of storage, price fluctuation, the absence of collective marketing were some of the Problems existing at farmers in potato value chain.

Table 8. Potato production and marketing constraints

\begin{tabular}{lll}
\hline Constraints & Number of respondents & Percentage \\
\hline Production Constraints & 99 & 82.50 \\
Disease & 56 & 46.67 \\
Insects/pests & 54 & 45.00 \\
Shortage of irrigation water & 47 & 39.17 \\
Shortage of improved seed & 42 & 35.00 \\
Wild animals & 24 & 20.00 \\
Absence of irrigation water & 20 & 16.67 \\
Low rain fall & 14 & 11.67 \\
Weeds & 10 & 8.33 \\
High rain fall & 10 & 8.33 \\
Natural hazard(frost, hail) & & \\
Marketing Constraints & 108 & 90.00 \\
Fluctuations and low of price & 74 & 61.67 \\
Product perishability & 68 & 56.66 \\
Individual marketing & 44 & 36.67 \\
Defective measures & 28 & 23.33 \\
Poor linkage with value chain actors & 27 & 22.50 \\
weak support of value chain supporters & 26 & 21.67 \\
Transport shortage & 24 & 20.00 \\
Low quality of product(no value addition) & 23 & 19.17 \\
Absence of modern storage & 22 & 18.33 \\
Lack of market information & & \\
\hline Source: Own survey result, 2015 & & \\
\hline
\end{tabular}

Source: Own survey result, 2015

Diseases and pests: A larger proportion of the respondents reported that diseases $(82.5 \%)$ and pests $(46.67 \%)$ was the severe problem that farmers currently faced. According to key informant interview with agricultural experts' bacterial wilt, late blight diseases and insects were the major problems prevalent in the area. It is possible to control late blight disease by using chemicals but bacterial wilt is becoming a major limiting factor for potato production in all seasons mostly occurred in rain fed and residual production systems that remains unresolved till now. According to key informant interview with Adet Agricultural Research center researcher the main causes of widespread of disease in the area were improper potato farm management practices and not practicing crop rotation.

Limited access to supply of agricultural inputs: The most important physical inputs for potato production are improved seeds, fertilizers, pesticide/herbicides and irrigation water. Farmers replied limited access and supply of inputs like improved seed as their production problem due to absence of potato seed multiplying and distributing enterprise where farmers get inputs from informal seed system they purchased from private traders or prepare their own seeds locally and remoteness of input supplying site for chemicals and often for fertilizers. Irrigation water is the main resource in potato production a significant number of farmers reported that irrigation water shortage $(45 \%)$ as a problem because of improper water management and traditional irrigation water development systems observed in most kebeles even though rivers are there in the locality.

Postharvest and marketing problems: The use of traditional harvest tools, poor product handling, perishability and lack of proper storage facility among postharvest problems and price fluctuation, low price and poor linkage of value chain actors, absence of group marketing, lack of fair weight (defective measures), absence of formal marketing information and far market distance as the problems they are among marketing problems occurred in potato farmers. Price fluctuation is the main problem of farmers in the study area, about $90 \%$ of the sample farmers replied that price fluctuation and low price are their marketing problem (Table 8). Potato selling and buying process is mainly undertaken at farm gate and pricing is usually estimated mostly at farm field before harvested and others estimated by using sack as if it were standard measurement which is considered as defective. Regarding potato handling out of those households store potato about $50 \%$ of the farmers used locally prepared beds to store, $43.3 \%$ store the product on floor of the house, $3.26 \%$ used separate traditional house and the rest $3.26 \%$ of the households used modern type of storage. The main benefit of storage helps the farmer to sell when the price is good but the result indicated that farmers were not benefited because a majority of farmers do not had a modern way of storage.

Lack of strong cooperatives: Although there are multipurpose and irrigation farmers cooperatives in the 
study area which were established to safeguard farmers' and rights over their input supply and market of products. But due to cooperatives performed as not expected farmers were not benefited from production of potato, ultimately sell their produce at low price.

The problems identified by traders in the value chain were supply shortage, poor product handling (perishability and absence of storage facility), price fluctuation, administrative problems ( lack of sectorial support) and problem in working place specially in Injibara and rural district markets were the most important problems which have been raised by traders. Traders reported absence of proper storage facility and product perishability as the main problems in potato trading which cause price fluctuation and lower price. About $90.48 \%$ of the traders reported that price fluctuation as a problem. Irregular supply of the product to the market (74.29\%), perishability $(51.43 \%)$, limited dish $(51.43 \%)$ and relatively costly in off season period $(51.43 \%)$ were the major problems at consumption level of potato value chain. Researchers were identified a wide range of challenges in vegetables value chain in Nepal, problems with respect to inputs like unavailability of fertilizers, low quality seeds, irrigation facilities, poor linkage and coordination among value chain actors, problem of trust between value chain actors, limited collection centers, unreliable market information, and lack of proper post-handling and transportation and lack of proper operation guidelines were hindrances of well performance of vegetable value chain (Regmi, 2013; HVAP, 2011 \& USAID, 2008). Senyolo et al. (2018) dds problems like lack of technical advice on production, lack of packaging and processing services, poor infrastructure, deficiency of contractual agreements between actors, and lack of access to finance.

Presence of rivers for irrigation use, suitable agro ecology, presence of experienced and interested farmers in production of potato, the support of different NGOs'(like IFAD, GIZ) and governmental organization (Woreda agricultural offices and Adet agricultural research center), the presence of FTC and Kebele agricultural office at kebele level which are playing great role in improving farmers livelihoods regarding potato production, availability of multipurpose and irrigation development primary cooperatives which can supply input and buy products even though they are not involved yet are among the opportunities which can be exploited in production of potato. On the other hand, availability of market demand throughout the year, growing number of buyers, high experience in potato production and marketing were some of the opportunities of potato. The natural proximity to market and being found on high demanding cites like Bahir Dar, Benshangul Gumuz region. Potato also consumed by both rural and urban societies across in all income groups taken as a good opportunity.

\section{Conclusion}

This study revealed that the main value chain actors being input suppliers, producers, collectors, wholesalers, retailers and consumers (including hotels and restaurants). Producers themselves, private seed traders, primary cooperatives, private chemical suppliers and NGOs were the actors involved in the input supply activities. Only small scale farmers are involved in potato production in the study area. There are also governmental and nongovernmental organizations that provided support services to potato value chain. The main supporters of the potato value chain in the study area are office of agriculture, office of trade and transport, Adet Agricultural Research Center, IFAD, GIZ, Amhara Saving and Credit Institution (ACSI) and commercial banks. Potato produced in the study area passes through several intermediaries and went out to different geographical locations, with little value being added before reaching the end users. Out of the total costs of production seed accounts $38.43 \%$ of the total production cost to farmers and net return of $27.33 \%$ selling price.

\section{Recommendations}

To improve the value chain of potato in the study area, value chain supporters' work to promote and encourage the production and dissemination of quality seed systems since the area is suitable for seed and ware potato production. Furthermore, strengthening provision of training on proper farm management and postharvest handling, establishing modern irrigation systems across main rivers in the district, and strengthening primary cooperatives financially and technically that can supply inputs and at the end it purchase the product to sell to distance areas at premium price to benefit the potato farmers. The arrangements will facilitate: use of common transport; exchange of marketing information while strengthening negotiation; bargaining position of farmers, and also make contracting and enforcement of contracts easier.

\section{References}

Abduselam, F., Zekarias, S. and Mequanent M. (2018). Value chain analysis of Potato in Dedo district of Jimma zone, Ethiopia. The International Journal of Business Management and Technology, 2 ( 6) : 43-49; ISSN: 2581-3889.

AGRIBiz (Ethiopia Agribusiness Guide). (2015). http://agribiz.et/value-chains/potato/. (Accessed on June 15, 2015).

Bezabih, E. and H. Gebremedhin. (2007). Constraints and Opportunities of Horticulture Production and Marketing in Eastern Ethiopia. Dry Lands Coordination Group. Report No 46. 
Bezabih, E. and Mengistu N. (2011). Potato value chain analysis and development in Ethiopia: Case of Tigray and SNNP regions. International potato center (CIP-Ethiopia), Addis Ababa.

CA (Central Statistical Agency). (2012). Crop Production Forecast Sample Survey. CSA, Addis Ababa, Ethiopia.

Chanie, Yazie \& Teshome, Akalu, Tigabu, Yalfal \& Baye, Berihun. (2017). Characterization of potato production, marketing, and utilization in North Western Amhara Region, Ethiopia. Journal of Horticulture and Forestry. 9. 17-25. 10.5897/JHF2015.0406.

CIP (International Potato Center). (2011). Roadmap for Investment in the Seed Potato Value Chain in Eastern Africa. CIP, Lima, Peru.

CSA (Central Statistical Agency). (2013). Agricultural Sample Survey: Report on Area and Production of major crops. CSA, Addis Ababa, Ethiopia.

CSA (Central Statistical Agency). (2015). Agricultural Sample Survey: Report on Area and Production of major crops.CSA, Addis Ababa, Ethiopia.

Dawit,S.T. and Fitsum H. (2016). Structure and Performance of Vegetable Marketing in East Shoa Zone, Oromia Region, Ethiopia. Journal of Marketing and Consumer Research ISSN 2422-845. 26; 7-16.

EIA (Ethiopia Investment Agency). (2012). Investment Opportunity Profile for the Production of Fruits and Vegetables in Ethiopia. Addis Ababa, Ethiopia.

FAO (Food and Agriculture Organization). (2008). Potato World: Africa International Year of the Potato. http://www.potato2008.org/en/world/africa.html.

FAO.(Food and Agriculture Organization). https:/www.google.com/search?q=faostat+data\&oq=faos\&aqs=chrome.0.69i59j69i57j69i59j69i60.3180j0j $7 \&$ sourceid $=$ chrome\&ie $=$ UTF-8

Gebremedhin,W., Endale, G. and Berga, L. (2008). Overview of Trends in Root and Tuber Crops Research in Ethiopia. In Root and Tuber Crops: The untapped Resources. Pp. 1-5. in:

GebremedhinWoldegiorgis, EndaleGebre and BergaLemaga ((Eds.) Ethiopian Institute of Agricultural Research (EIAR), Addis Ababa.

Gildemacher, P.R. (2012). Innovation in seed potato systems in Eastern Africa. Wageningen University, Wageningen, The Netherlands.

Haggblade, S., Veronique, T., John, S., Nango, D. and Diallo, B. (2012). A Conceptual Framework for Promoting Inclusive Agricultural Value Chains: Prepared for the International Fund for Agricultural Development (IFAD). Michigan state university, USA.

Hirpa, A., Meuwissen, M.P.M. and Tesfaye, A. (2010). Analysis of Seed Potato Systems in Ethiopia. Am. J. Pot Res 87, 537-552. doi:10.1007/s12230-010-9164-1.

HVAP. (2011). A report on value chain analysis of offseason vegetables. High Value Agriculture Project (HVAP) in Hill and Mountain Areas.

Joshi, S. R and Gurung, B. R. (2009). Potato in Bhutan, value chain analysis. Regional Agricultural Marketing and Cooperatives Office, Department of Agricultural Marketing and Cooperatives, Ministry of Agriculture, Mongar, India.

Kassa T. A. (2014). Potato value chain in Ethiopia: Cases of Sinan and Bibugn districts in East Gojjam. Time Journals of Agriculture and Veterinary Sciences, 2(6):114-124.

Masuku, M.B and Xaba, B.G. (2013). Factors Affecting the Productivity and Profitability of Vegetables Production in Swaziland. Journal of Agricultural Studies ISSN 2166-0379 1 ( 2):37-52. doi:10.5296/jas.v1i2.3748.

Pankrust, R. (1964). Notes on a History of Ethiopian Agriculture.

Regmi Khim Raj. (2013). Value chain analysis of vegetables in Palpa district of Nepal. Economic Affairs 58 (2) : 135-146.

Senyolo, G.M., Edilegnaw, W. and Ortmann, G.F. (2018). Analysing the value chain for African leafy vegetables in Limpopo Province, South Africa, Cogent Social Sciences 4: 1509417.

Tekalign. T. (2010). Potato Value Chain Analysis in Eastern Ethiopia: A study conducted as part of a project entitled which is within the Edulink program of Europe Aid, coordinated by Humboldt Universitätzu Berlin, Germany.

USAID. (2008). A comparative case study of high-value vegetable value chains in Nepal: Guided case studies in value chain development for conflict-affected environments. Washington DC.

Yamane, T. (1967). Statistics: An Introductory Analysis, $2^{\text {nd }}$ Edition. harper and Row, New York. 